\title{
アルミナ膜の細孔形状のキャラクタリゼーション
}

\author{
清 水康 利・松下幸之助・三浦＼cjkstart勲・矢沢哲夫*・江口清 久* \\ 東陶機器 (株) 研究所水処理研究室, 802 北九州市小倉北区中島 2-1-1
$*$ 工業技術院大阪工業技術試験所, 563 池田市緑丘 1-8-31
}

\section{Characterization of Pore Geometry of Alumina Membrane}

\author{
Yasutoshi SHIMIZU, Kohnosuke MATSUSHITA, Isao MIURA, Tetsuo YAZAWA* \\ and Kiyohisa Eguchi*
}

\begin{abstract}
( Water Research Lab., Research \& Development Div., TOTO Ltd., 2-1-1, Nakajima, Kokurakita-ku, Kitakyushu-shi 802 ) *Goverment Industrial Research Institute, Osaka, 8-31, Midorigaoka 1-chome, Ikeda-shi 563

Pore radius and tortuosity of an alumina membrane were calculated from the flux through the membrane and liquid capillary rise rates of several solvents, and compared with the values obtained by convensional methods. Tortuosity value by this method agreed well with that obtained by the measurement of effective ionic conductivity of the alumina membrane. However, pore radius by this method was 1.17 times larger than that by the Hg intrusion method. This difference was explained by the pore geometry that is, pores in the alumina membrane are rectangle because the membrane was prepared by packing alumina particles. By the Hg intrusion method, measured pore radius corresponds to that of inscribed circles for rectangle alumina pores. On the other hand, measured value by the transport phenomena of liquids through membrane voids is equivalent to the radius of a circle of which area is comparable to the cross sectional area of a rectangle alumina pore. Therefore, geometrical coefficient which accounts for the discrepancy of pore shape from circle was derived by comparing the pore radius values by this method with those by $\mathrm{Hg}$ intrusion method.
\end{abstract}

[Received September 21, 1987; Accepted December 15, 1987]

Key-words : Membrane, Alumina, Pore diameter, Tortuosity

\section{1. 緒 言}

近年, 各種プロセスへの膜分離法の応用研究が活発に 行われている. 特に, セラミック膜の応用は, 膜素材の 耐環境性, 機械的強度等の特徵により, システムの長寿 命化が期待される. あるいは, 膜の洗浄に逆洗等の物理 的洗浄法の適応が可能, と言った点で注目されてい $3^{11,21}$.

ところで，セラミック膜は，一般にアルミナ等の骨材 粒子を充填して構成するため, その細孔径分布はシャ一 プで, かつ, 孔が屈曲した構造となる31.これらの構造 上の特徵である細孔径の均一性及び細孔の屈曲性は, 膜 のごとく材料間の空隙を流体の流路としてとらえる場 合, 流体の透過抵抗を支配し, また, メンブレンバイオ リアクター用菌体分離膜等の精密沪過膜として用いる場 合には，原水中の粒子成分の膜への目詰まり性に大きな 影響を与える。したがって, セラミック膜の各種プロセ スへの応用のためには, 細孔径, 屈曲率の正確な把握が 必要である。

精密沪過膜の細孔径の評価には, 水銀圧入法が広く用 いられている. また, 屈曲率は, 電解質溶液中に浸漬し た多孔体の空隙の有効電気伝導率より求如れる ${ }^{4)}$. 著 者らは, メンブレンバイオリアクタ一用アルミナ膜の細
孔径及び屈曲率を, 膜の純水及び有機溶媒の透過流束值, 浸透速度值より算出し, 従来法による值と比較検討する とともに, 特に測定法の違いによる細孔径の值の差異に ついて考察した。

\section{2. 実 験}

\section{1 膜透過流束測定}

溶媒の膜透過が Poiseuille の法則に従う粘性流であ るとすると, 膜透過流束：Jは，（1）式で与えられる

$$
J=\frac{r^{2} \varepsilon \Delta P}{\tau^{2} 8 \eta d}
$$

式中, $r, \varepsilon, d, \tau$ は, それぞれ膜の細孔半径, 空隙率, 膜厚, 細孔の屈曲率で, $\Delta P$ は膜差圧, $\eta$ は溶媒の粘度 である。

各種溶媒の $J$ 值を測定することで $(1)$ 式より $r / \tau$ 值が求まる. そこで, 表 1 に物性を示す円板状アルミナ 膜を用いて図 1 の沪過器により純水, エタノール,アセ トン, トルエン, 及び四塩化炭素の膜透過流束を測定し た。純水は, イオン交換, 蒸留後, 公称孔直径 $0.2 \mu \mathrm{m}$ の酢酸セルロース精密沪過膜 (東洋濾紙(株), TCR-020) で除粒子した水を用いた。有機溶媒は, 特級試薬をその まま用いた．測定時の液温は, 沪過器のジャケット部分 


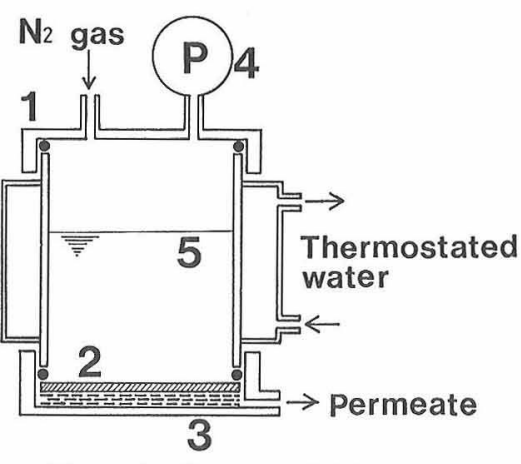

Fig. 1. Shematic diagram of filtration apparatus. 1 : SUS 304 vessel, 2: Alumina membrane, 3: Support screen, 4: Pressure gauge, 5 : Liquid

Table 1. Characteristics of alumina membrane.

\begin{tabular}{ll}
\hline Composition & $:>99 \% \alpha \cdot \mathrm{Al}_{2} \mathrm{O}_{3}$ \\
Pore radius & $\vdots 0.23 \mu \mathrm{m}$ \\
Porosity & $38 \%$ \\
Dimension (Dia. X Thick.) & $76 \mathrm{~mm} \times 1.5 \mathrm{~mm}$ \\
\hline
\end{tabular}

*) Measured by $11 \mathrm{~g}$ intrusion method

に恒温水を循環し, $20^{\circ} \mathrm{C}$ に設定した。膜は, 実験に先 立ち, $100 \mathrm{~mol} / \mathrm{dm}^{3}$ 硝酸で洗浄した.

また，アルミナ膜をオクタデシルジメチルクロロシラ ン (以下 ODS と略記する) で表面改質処理し，アルミ ナ表面水酸基をアルキル基化した後, 図 1 の沪過器によ り純水透過流束の圧力依存を調べた. 表面改質処理の詳 細は，前報 ${ }^{6)}$ に記した。 ODS 改質膜への純水の接触角 は $103^{\circ}$ である7!。

\section{2 浸透速度測定}

多孔材料の一端から材料内部空隙へ溶媒が浸透する速 度は, 材料中への浸透溶媒の重量值 : $W$ の経時変化と して（2）式で示される6!.

$$
\frac{W^{2}}{t}=\frac{r}{\tau^{2}} \frac{\gamma_{\mathrm{L}} \cos \theta S^{2} \varepsilon^{2} \rho^{2}}{2 \eta}
$$

式中 $t$ は浸透時間, $\gamma_{\mathrm{L}}, \rho, \theta$ はそれぞれ溶媒の表面張力, 密度及び材料への接触角である. $S$ は，材料接液部の 断面積である.

そこで, 直径 $76 \mathrm{~mm}$, 厚さ $1.5 \mathrm{~mm}$ の円板状アルミナ 膜を幅 $10 \mathrm{~mm}$, 長さ $60 \mathrm{~mm}$ に切断して $100 \mathrm{~mol} / \mathrm{dm}^{3}$ 硝 酸で洗浄後, 純水ですすぎ, $120^{\circ} \mathrm{C}$ で真空乾燥して浸透 速度測定試料とした。測定には長計量器製浸透速度測定 装置を用い，装置の天科部から試料を吊した後，試料下 端へ溶媒の液面を接触させて試料への溶媒の浸透速度を 重量値の経時変化としてとらえた. 測定法の詳細は, 前 報

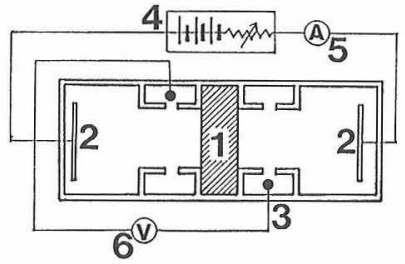

Fig.2. Shematic diagram of ionic conductivity measurement cell,

1: Alumina membrane, 2 : Working electrode,

3: Reference electrode, 4:DC power source,

5:Ammeter, 6: Potentiometer

定時に用いた物と同様である.

アルミナ表面に対する溶媒の接触角 : $\theta$ は, アルミナ 焼結体を用いて液滴法により測定した。

以上の実験から $r / \tau^{2}$ 值を求め, 膜透過流束值より求 めた $r / \tau$ 值と合わせて $r, \tau$ それぞれの值を決定した。 なお, 空隙率： $\varepsilon$ は膜の空隙を水置換してその重量值よ り求めた.

\section{3 電気伝導率測定}

多孔材料中の空隙が屈曲した円筒より構成されている とすると, その屈曲率 : $\tau$ は, 円筒の実長 $: l_{\mathrm{e}}$ と見掛け の長さ $: l$ との比 $: l_{\mathrm{e}} / l$ として表される. 屈曲率は, 電 解質溶液中に浸漬した多孔体の有効電気伝導率 : $\lambda_{\text {eff }}$ を 測定することにより $(3)$ 式より計算できる. 式中 $\lambda$ は電解質溶液の電気伝導率である.

$$
\lambda_{\text {eff }}=\frac{\varepsilon}{\tau^{2}} \lambda
$$

そこで, JIS C 2313 により規定された鉛蓄電池用セ パレーターの抵抗測定法にならい, 円板状アルミナ膜空 隙の有効電気伝導率測定を行った. 測定セルの概略を図 2 に示す。電解質溶液には $1 \mathrm{~mol} / \mathrm{dm}^{3}$ 塩化カリウム水 溶液を用い, 電極にはニッケル板を用いて直流定電圧電 源（4）により作用電極（2）間に0〜1.7Vの範囲で 直流を通電して電解質溶液を含浸した膜部分（1）に電 位勾配を生じさせ，照合電極（3）により膜両表面間の 電位差を測定した，膜の電位勾配值と通電電流値から膜 内空陌の有効電気伝導率を算出した。なお, 液温は, $20^{\circ} \mathrm{C}$ とた。

\section{4 水銀圧入法}

アルミナ膜は,その素材の圧縮率が極めて小さいため, 水銀圧入法によりその細孔径の測定が可能である．水銀 圧入法での圧入圧力と細孔径には，(4) 式の関係が成 り立つ.

$$
\Delta P=-\frac{2 \gamma_{\mathrm{L}} \cos \theta}{r}
$$

式中のアルミナへの水銀の接触角 $: \theta$ には, アルミナ焼 結体を用いて液滴法により測定した值：137を用いた。 


\section{3. 結果と考察}

各種溶媒による膜透過流束値及び $r / \tau$ 値を表 2 に示 す。膜透過流束は溶媒の粘度によってのみ決まっており， 各溶媒で $r / \tau$ 值は $0.145 \times 10^{-6} \mathrm{~m}$ で一定値となってい る。

膜への溶媒の浸透速度は，各溶媒の $W^{2}$ 対 $t$ プロッ トが図 3 に示すごとく原点を通す直線性を示すことか ら，（2）式による解析が可能である。アルミナに対す る溶媒の接触角の值を用いて計算した $r / \tau^{2}$ 值もほぼ一 定の值を示した（表 3 ）. $r / \tau^{2}=7.6 \times 10^{-8} \mathrm{~m}$ とすると, 細孔半径及び屈曲率はそれぞれ $r=0.27 \mu \mathrm{m} ， \tau=1.91$ となった。

アルミナ膜中空隙の有効電気伝導率測定より求めた $\tau$ は1.88であった。

$\tau$ は，電気伝導率測定による值と，溶媒の膜透過，浸 透速度より求めた值がよく一致している。粒子充媜層の $\tau$ は大略 1.4〜2.2の值をとり，また，球形粒子充塡層 では $\tau=1.57$ 之報告されている ${ }^{41,8)}$. 実験に用いた膜の 空隙率は 0.38 之最密充填の空隙率之同等で，かつ，図 4 に示すように膜が角張った粒子で構成されていること

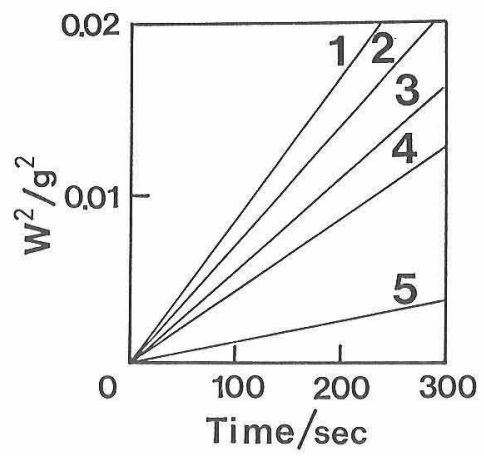

Fig. 3. The plot of $W^{2}$ : permeation weight vs. permeation time of alumina membrane.

$1: \mathrm{CCl}_{4}, 2:$ Water, $3:$ Acetone, $4:$ Toluene, $5:$ Ethanol

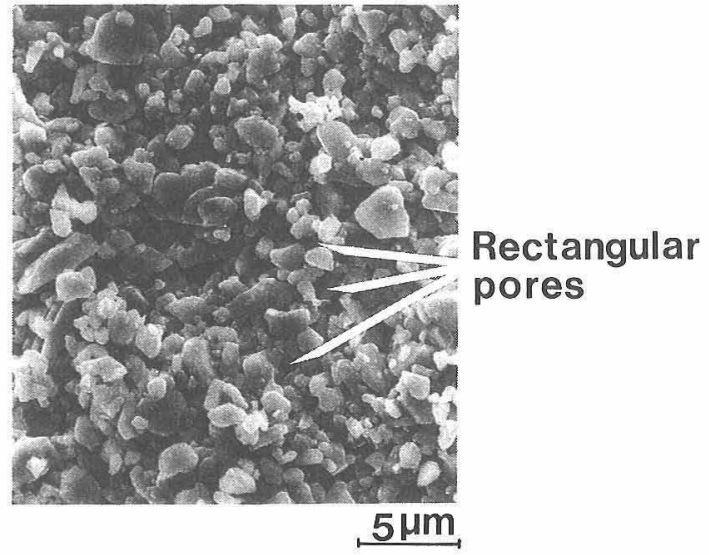

Fig. 4. SEM photograph of alumina membrane.
Table 2. $J$ : flux and $r / \tau:$ (pore radius)/(tortuosity) of alumina membrane.

\begin{tabular}{lcl}
\hline Liquid & $\left.J\left(\mathrm{~m}^{3} / \mathrm{m}^{2} \cdot \mathrm{d}\right)^{*}\right)$ & $\mathrm{r} / \mathrm{r}\left(\times 10^{-6} \mathrm{~m}\right)$ \\
\hline later & 5.64 & 0.145 \\
Ethanol & 4.79 & 0.145 \\
Acetone & 18.22 & 0.147 \\
Toluene & 9.62 & 0.145 \\
$\mathrm{CCl}_{4}$ & 5.79 & 0.144 \\
\hline
\end{tabular}

*) at $20^{\circ} \mathrm{C}, \triangle \mathrm{P}=0,1 \mathrm{MPa}$

Table 3. $\theta:$ contact angles, $W^{2} / t:$ rates of capillary rise and $r / \tau^{2}:$ (pore radius)/(tortuosity) $)^{2}$ of alumina membrane for liquids.

\begin{tabular}{|c|c|c|c|}
\hline \multicolumn{4}{|c|}{ (degree) $\left(\times 10^{-11} \mathrm{Kg}^{2} / \mathrm{s}\right)\left(\times 10^{-8}\right.$} \\
\hline Hater & 36 & 6.95 & 7.60 \\
\hline Ethanol & 29 & 1.26 & 7.72 \\
\hline Acetone & Spread*) & 5.48 & 7.62 \\
\hline Toluene & Spread ${ }^{*)}$ & 4.26 & 7.50 \\
\hline $\mathrm{CCl}_{4}$ & Spread $^{*)}$ & 8.35 & 7.58 \\
\hline
\end{tabular}

*)Calculated as 0 degree

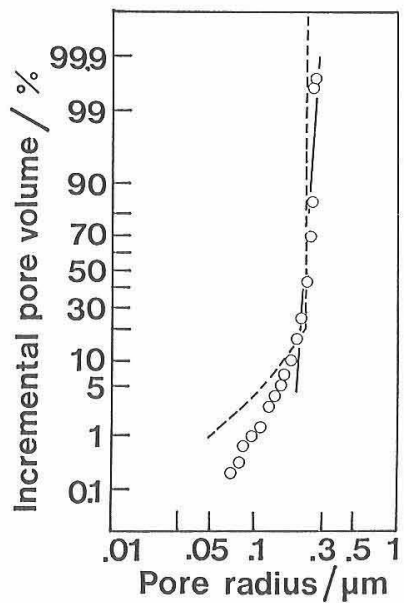

Fig. 5. Pore size distribusion of alumina membrane. - - : Measured by $\mathrm{Hg}$ intrusion method,

: Calculated by the $\mathrm{Hg}$ intrusion model for rectangular pore

を考慮すると，本実験で得られた $\tau$ 值は妥当であると 推察される。

一方，水銀圧入法で測定したアルミ十膜の細孔半径： $r_{\mathrm{H}_{\mathrm{g}}}$ は，0.23 $\mu \mathrm{m}$ に平均值を有するほぼ対数正規分布を 示す (図 5 ). 


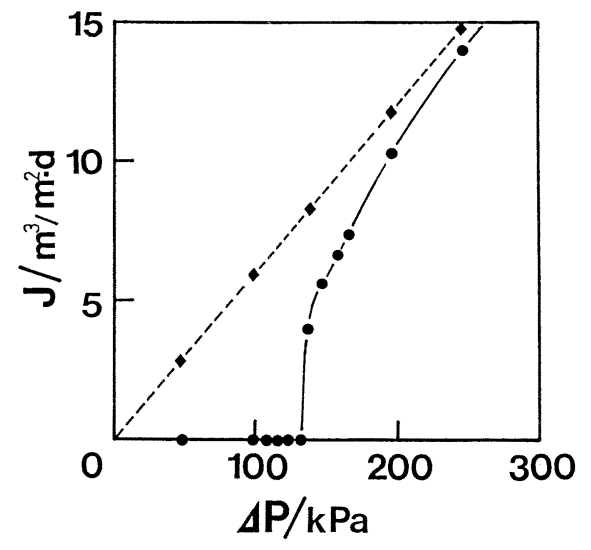

Fig. 6. The plot of $J$ : flux vs. $\Delta P$ : trans-membranepressure for hydrophobic and hydrophilic alumina membrane.

- : Hydrophobic alumina membrane (Surface modified alumina membrane)

-... : Hydrophilic alumina membrane (Natural alumina membrane)

また, 疎水化アルミナ膜の純水透過流束の圧力依存を 疎水化処理前の膜の純水透過流束値とともに図 6 に示す が，純水透過は $132 \mathrm{kPa}$ 以上で起きており，この圧力 值を用い（4）式から求めた最大細孔半径は $0.25 \mu \mathrm{m}$ である。

膜透過流束, 浸透速度より求めた細孔半径と水銀圧入 法による值の差を, 細孔形状に着目して説明を試みた. アルミナ膜の空隙は, 図 4 の電子顕微鏡写真に示すごと く矩形に近い.そこで細孔形状を“正方形の孔”と，モ デル化してモデルの透過流束，また，モデルへの水銀圧 入について考察する.

まず，水銀圧入においてモデルを想定すると，水銀の 細孔内への圧入は, 圧力の増加に伴い図 7 に示すごとく 初めは孔への内接円柱状に進入し, 次第に孔の四隅の方 まで水銀が満たされると考えられる.そこで一辺の長さ が $r_{\mathrm{H}_{\mathrm{g}}} \times 2$ の正方形の孔への水銀圧入による見掛けの細 孔径分布を武算した. 結果を実際のアルミナ膜の測定結 果と共に図 5 に示す. 測定結果では, 小孔径側で, その 積算細孔容積が全体の $10 \%$ 以下の領域において, 細孔

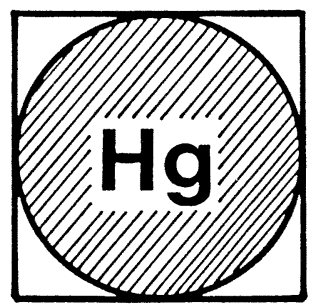

Fig. 7. Rectangular pore model which intrude mercury.
径が対数正規分布から外れて広い分布を示しているが, モデルを想定した試算は，この小孔径側の特徵をよく表 現している.

モデル膜の透過流束を考えた場合, 膜に対し接触角が $90^{\circ}$ 以下の液体には膜が自発的に濡れるため, その四角 孔全体が液体の流路として用いられる. よって, 膜透過 流束より求めた細孔径はその四角孔の断面積に相当する 円の半径として与えられる. 一方, モデルへの水銀圧入 では, その細孔径は四角孔への内接円の半径として与え られる.したがって, モデルにおいて, 膜透過流束より 求めた細孔径は水銀圧入法による值の 1.13 倍となる. この計算值は, 実際の膜での溶媒の透過流束, 浸透速度 から求めた細孔径と水銀圧入法での測定值との比 $: 1.17$ より小さいものの, 妥当であるとも考えられる.

一方, 疎水化アルミナ膜の場合, もし, 膜の細孔径分 布が広くて, そのため, 透過流束, 浸透速度より求めた 細孔径が実際の平均值より大きく出るとすれば, 純水の 透過開始圧力から求めた最大細孔半径は, 膜透過流束, 浸透速度から求めた細孔半径及び水銀圧入法による值よ り大きいはずである。しかし，最大細孔半径は $0.25 \mu \mathrm{m}$ で, 膜透過流束, 浸透速度より求めた值を超えない。し たがって, 膜透過流束, 浸透速度より求めた細孔径と, 水銀圧入法による值との不一致を膜の細孔径分布の広が りによる, とするのは妥当ではない.

水銀圧入法による多孔材料の細孔径分布測定では, 貫 通孔と閉じた孔の区別がつかないにもかかわらず，膜の 水銀圧入法の測定結果を貫通孔のデータと見なして考察 を進めた．これは，疎水化したアルミナ膜の純水透過流 束から試算した見掛けの細孔径分布 ${ }^{9)}$ が, 水銀圧入法で 測定した細孔径分布とほぼ一致することから，今回実験

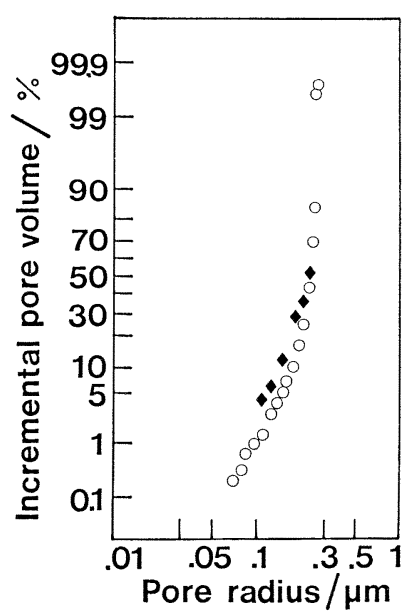

Fig. 8. Pore size distribusion of alumina membrane. $\circ$ : Measured by $\mathrm{Hg}$ intrusion method,

- : Calculated by the pure water flux in the hydrophobic alumina membrane 
に用いたアルミナ膜の細孔は, 貫通孔よりなると考えて 問題ない. 疎水化アルミナ膜の純水透過流束より求めた 見掛けの細孔径分布を図 8 に水銀圧入法による膜の測定 結果とともに示す.

以上の実験結果から, 膜の透過流束, 浸透速度より計 算した細孔半径と水銀圧入法で求めた值の不一致は, ア ルミナ膜の製法に基づくその細孔形状に起因するとして 説明できる.すなわち, 今回実験に用いたアルミナ膜は, 角張った粒子の充填により構成されているため, その細 孔は矩形に近い孔となっている.この孔の半径を水銀圧 入法で計ると孔に内接する円の半径としての值が得ら れ, また, 膜透過流束, 浸透速度測定といった膜を濡ら す液体の膜内の移動現象から求めた值は, その孔の真の 断面積に相当する円の半径となる.

したがって, 膜の透過流束值, 浸透速度値を測定する ことで膜の細孔半径, 屈曲率が求まることが分かった. また, 細孔半径の值で, 本方法で求めた值と水銀圧入法 による值を比較することで孔の断面形状の円形からのズ レとしての “形状係数”が得られることが示唆される.

\section{4. 結 論}

アルミナ膜の細孔半径, 屈曲率を, 膜の各種溶媒の透 過流束, 浸透速度より計算し, 得られた值と水銀圧入法, 電気伝導率測定から求めた値とを比較検討した。 その結
果, 屈曲率は, 本報告による值と電気伝導率測定から求 めた值が一致した. しかし, 細孔半径は, 膜透過から求 めた值が水銀圧入法による值の 1.17 倍となった。この 差は, アルミナ膜が粒子の充填でなるためその空隙が矩 形に近いという細孔形状特性を考慮することで説明でき る. また, 精密沃過膜としてのアルミナ膜において, こ れらの值の意味を考えた場合, 膜透過から求めた細孔半 径と水銀圧入法による值は, それぞれ, 溶媒の透過性に 係わる細孔半径, 膜での原水中の粒子成分の阻止に係わ る細孔半径とそれぞれ位置付けられ, 細孔径の值を評価 する立場によりこれらの值を使い分ける必要があること が分かった。

\section{文献}

1) 中尾真一, 斉藤史代, 木村尚史, 生産研究, 37, 279-87 (1985).

2) 木村尚史, ケミカル・エンジニヤリング, $12,873-76$ (1983).

3) 懸 欣司, 化学装置, 3, 87-95 (1983).

4) J. van Brakel, Powder Technology, 11, 205-36 (1975).

5) 中垣正幸編, “膜学入門”, 喜多見書房, (1978) p.1.

6）清水康利, 矢沢哲夫, 柳沢日出男, 江口清久, 窯協, 95, 1067-72 (1987).

7）清水康利, 矢沢哲夫, 柳沢日出男, 江口清久, 窯協, 95, 1169-74 (1987).

8) 竹原善一郎, 小久見善八, 電気化学, 53, 75-79 (1985).

9）永澤 満, “高分子膜”, 地書人館, (1975) p. 90 . 